This article was downloaded by: [Frank Tomasulo]

On: 13 May 2014, At: 18:17

Publisher: Routledge

Informa Ltd Registered in England and Wales Registered Number: 1072954 Registered office: Mortimer House, 37-41

Mortimer Street, London W1T 3J H, UK

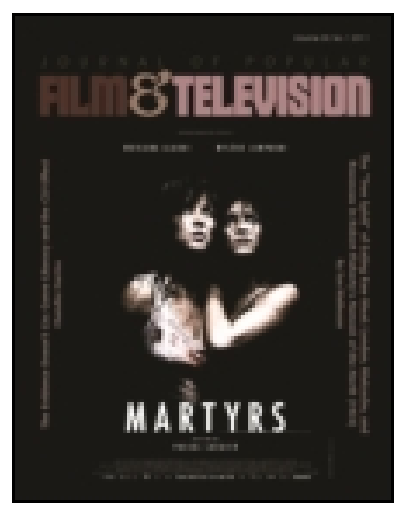

J ournal of Popular Film and Television

Publication details, including instructions for authors and subscription information: http:// www. tandfonline.com/loi/ vjpf20

\title{
Colonel North Goes to Washington: Observations on the Intertextual Re-presentation of History
}

Frank P. Tomasulo ${ }^{a}$

${ }^{a}$ An associate professor in the Cinema and Photography Department, Ithaca College

Published online: $14 \mathrm{~J}$ ul 2010.

To cite this article: Frank P. Tomasulo (1989) Colonel North Goes to Washington: Observations on the Intertextual Re-presentation of History, J ournal of Popular Film and Television, 17:2, 82-88, DOI: 10.1080/01956051.1989.9943636

To link to this article: http:// dx. doi.org/ 10.1080/01956051.1989.9943636

\section{PLEASE SCROLL DOWN FOR ARTICLE}

Taylor \& Francis makes every effort to ensure the accuracy of all the information (the "Content") contained in the publications on our platform. However, Taylor \& Francis, our agents, and our licensors make no representations or warranties whatsoever as to the accuracy, completeness, or suitability for any purpose of the Content. Any opinions and views expressed in this publication are the opinions and views of the authors, and are not the views of or endorsed by Taylor \& Francis. The accuracy of the Content should not be relied upon and should be independently verified with primary sources of information. Taylor and Francis shall not be liable for any losses, actions, claims, proceedings, demands, costs, expenses, damages, and other liabilities whatsoever or howsoever caused arising directly or indirectly in connection with, in relation to or arising out of the use of the Content.

This article may be used for research, teaching, and private study purposes. Any substantial or systematic reproduction, redistribution, reselling, loan, sub-licensing, systematic supply, or distribution in any form to anyone is expressly forbidden. Terms \& Conditions of access and use can be found at http://www.tandfonline.com/page/termsand-conditions 


\section{Colonel North Goes to Washington Observations on the Intertextual Re-presentation of History}

\section{By FRANK P. TOMASULO}

n John Fiske's book Television Culture, he proposes that "a textual study of television involves three foci: intertextual relations, formal qualities, and socially situated readers and the process of reading." For Fiske, this tripartite division represents the study of discourses (systems of representation that allow for the sharing of meanings), codes (open or closed), and audiences (demographically differentiated subgroups of viewers). This article will apply Fiske's categories to one particular aspect of "television culture," the documentary coverage of live news events -in this case, the Iran-Contra hearings. The objective is to interrogate and illuminate some intersections between media theory and the nonfiction mode.

\section{Intertextual Relations}

Although Mikhail Bakhtin is often credited with coining the term "intertextuality," the view of a fictive text as a mosaic of citations-a LéviStraussian bricolage representing other, prior representations and not some underlying primal "reality"has been with us for centuries. Karl Marx, however, extended the concept of intertextuality by applying it to historical events. In the opening words of The Eighteenth Brumaire of Louis Bonaparte, Marx said, "Hegel remarks somewhere that all facts and personages of great importance in world history occur, as it were, twice. He forgot to add: the first time as tragedy, the second as farce."2

The Reagan era has certainly been filled with interdiscursive repetitions and citations of old and current movies ("Win one for the Gipper," "Star Wars," "The Evil Empire," "Go ahead, make my day," etc.). Now, not only are the fictional products of culture intertextually motivated, but so is the historical dynamic of the political system. In short, in our postmodern "culture of the simulacrum," intertextual relations establish the specific historicity of both fictional texts and real life. The televised Iran-Contra hearings (1987) of- fer a case study of the ways history imitates fiction. Indeed, it can be shown that the narrative structure, characters, and imagery of the televised hearings derived their force and power not only from their real-life occurrence, important contemporary political ramifications, and location in the mise-en-scène of prior scandal (the Senate Caucus Room, site of the Army-McCarthy and Watergate investigations), but from loosely connected intertextual sources, most notably Frank Capra's classic film $M r$. Smith Goes to Washington (1939).

Rather than "allegoricizing" media representations by pointing out homologies between fictional film characters and their real-life historical counterparts (Ivan the Terrible = Stalin, Indiana Jones = Reagan), ${ }^{3}$ the reverse can be demonstrated: that Oliver North is a flesh-and-blood avatar of a fictional predecessor, Capra's populist hero, Jefferson Smith. This is not to say that North, his attorneys, or the television networks consciously made a real-life "remake" of $\mathrm{Mr}$. 


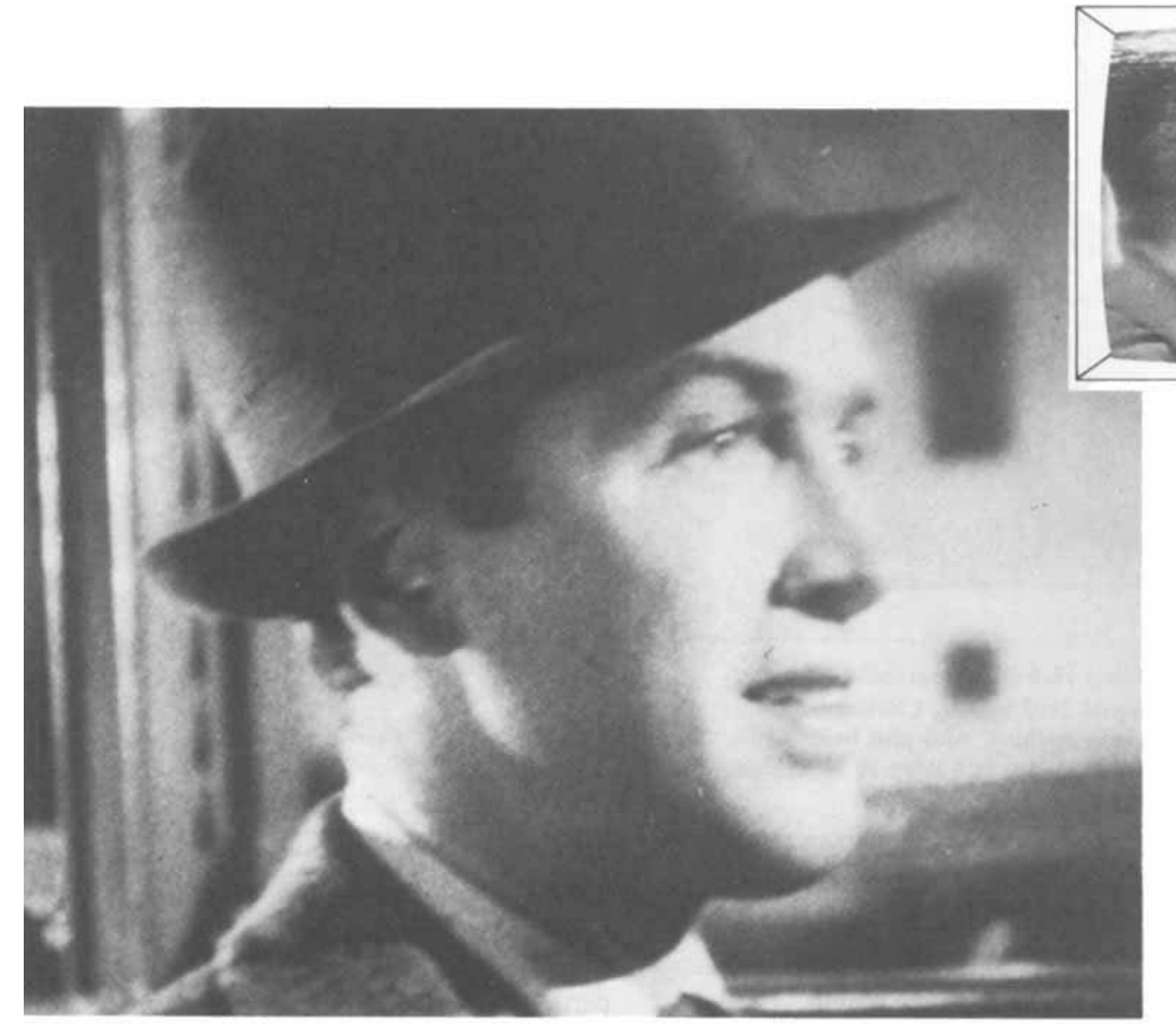

Smith Goes to Washington. What is being suggested is that the dominant symbolic forms and social formations of different eras often possess a common structure of feeling. Although ostensibly a "documentary" featuring "live event" television coverage of a political event, "The Ollie North Show" also reflected a mediated media reality based on the unconscious appropriation of American conventions and symbols, making it part of a collective stratum of cultural mythology drawn on in times of crisis. The historically "real" is continually contaminated by prior representations in this "age of electronic intertextuality." A sort of "made-forTV" history is the result, a docudrama of our national souls.

Consider the following plot synopsis: A sincere, boyish, and extremely patriotic young man is unexpectedly brought to Washington, D.C., to take his place among the nation's leaders. An attractive female assistant is assigned to help him fulfill his mission. However, by following the di- rectives of others, he gets involved in an illegal scheme and is made the fall guy by those he trusted. He loses his good name, but, rather than giving up, he chooses to fight for his reputation and for the ideals he sees being subverted. The climax occurs in Congress, right after the attempted suicide of one of his superiors. Although the senators are initially unresponsive, the common people rally to the young patriot's defense and vindicate him and the American political system itself. The morphology of this narrative schema fits both the Capra film and the Iran-Contra hearings, proving Umberto Eco's "back to the future" theory that intertextual harbingers of the future can be seen in a prior text. ${ }^{4}$

On the characterological level, Lieutenant Colonel Oliver North's Tom Sawyer image-complete with baby-blue eyes and dashing all-American good looks-is remarkably reminiscent of Capra's "boy ranger," Jefferson Smith. Both were history buffs. Both were excoriated in the media, yet won out over establish-
Oliver North is a flesh-and-blood avatar of a fictional predecessor ... Jefferson Smith. ... North got halo-like rim lighting for his holy zeal.

ment critics. Both invoked their families: Smith relied on his mother and his symbolic family of boy rangers; North conjured up his wife and children at every opportunity. These similarities make it ironic that right after the opening credits of Capra's film, a title card states that the characters and events depicted are fictitious. Although the movie was not a film à clef in 1939, the television hearings of 1987 may have transformed it from fictitious to retrospectively real.

In order to further compare and contrast Smith and North, one particular aspect of character development, speech, can be usefully studied. Nick Browne has traced the oedipal trajectory of Mr. Smith Goes to Washington through the agency of voice, particularly the title character's apprenticeship in public speaking. ${ }^{5} \mathrm{At}$ the film's beginning, Smith was stuttering and tongue-tied, especially with the pronoun "1." Before being confirmed in the Senate, he "has no voice in this chamber." Immediately after the induction ceremony, however, he was told that he could "talk his head off" (a foreshadowing of his filibuster scene). Later, his attempts at political speech were either too soft-spoken and full of paper-shuffling or too "strong-lunged." He was silenced after the preliminary hearings, yet returned hoarse-voiced to the Senate chamber to "speak his piece."

Oliver North's apotheosis was similarly accomplished through speech. Initially, he also had no voice in Con- 
gress, having chosen to plead the Fifth Amendment. He also relied heavily on code and deceptive speech in his covert activities. Eventually, Colonel North, as a latter day Mr. Smith, did "get it off his chest" by speaking directly and forthrightly on television, convincing the committee and the American public of his sincerity.

The supporting cast also contributed to the mise-en-abyme of intertextual allusion. The helpful, attractive, and adoring real-life assistant, Fawn Hall, who believed so strongly in her boss's cause, can be compared with her fictional predecessor, Clarissa Saunders (Jean Arthur), who also believed that her boss was beholden to a "higher law." CIA Director William Casey represented to North the Absent (dead) Father, and Ronald Reagan symbolically was the Good Father. Reagan delegated a number of Bad Father figures, most notably Poindexter and McFarlane. Jeff Smith's real father was dead, and his Bad Father figure, the troubled "Silver Knight," Senator Joseph Paine (Claude Rains), was an inadequate substitute. (The film's Good Father was no doubt the vice president, a thinly veiled FDR figure.)

Smith became the martyr who "died" and was resurrected when his Bad Father, Paine, symbolically "died" (attempted suicide). And Ollie North was, in his own words, "the only one on the planet Earth" earmarked for prosecution. As such, he became a martyr or scapegoat figure for his scurrilous superiors, some of whom died (Casey) or attempted suicide (McFarlane). (It's been reported that McFarlane decided to go on living after his suicide attempt as a result of viewing another Capra production, It's a Wonderful Life.) North's performance (and it was one) enabled him to rise from his ashes, just as Jefferson Smith did 50 years before. And the North persona and uniform fueled Ollie-mania even more than Jeff Smith's words and deeds inspired his 1939 audience-in part because political ideas have lost their content to the "impressions" of patriotism conveyed by North's telegenics and in

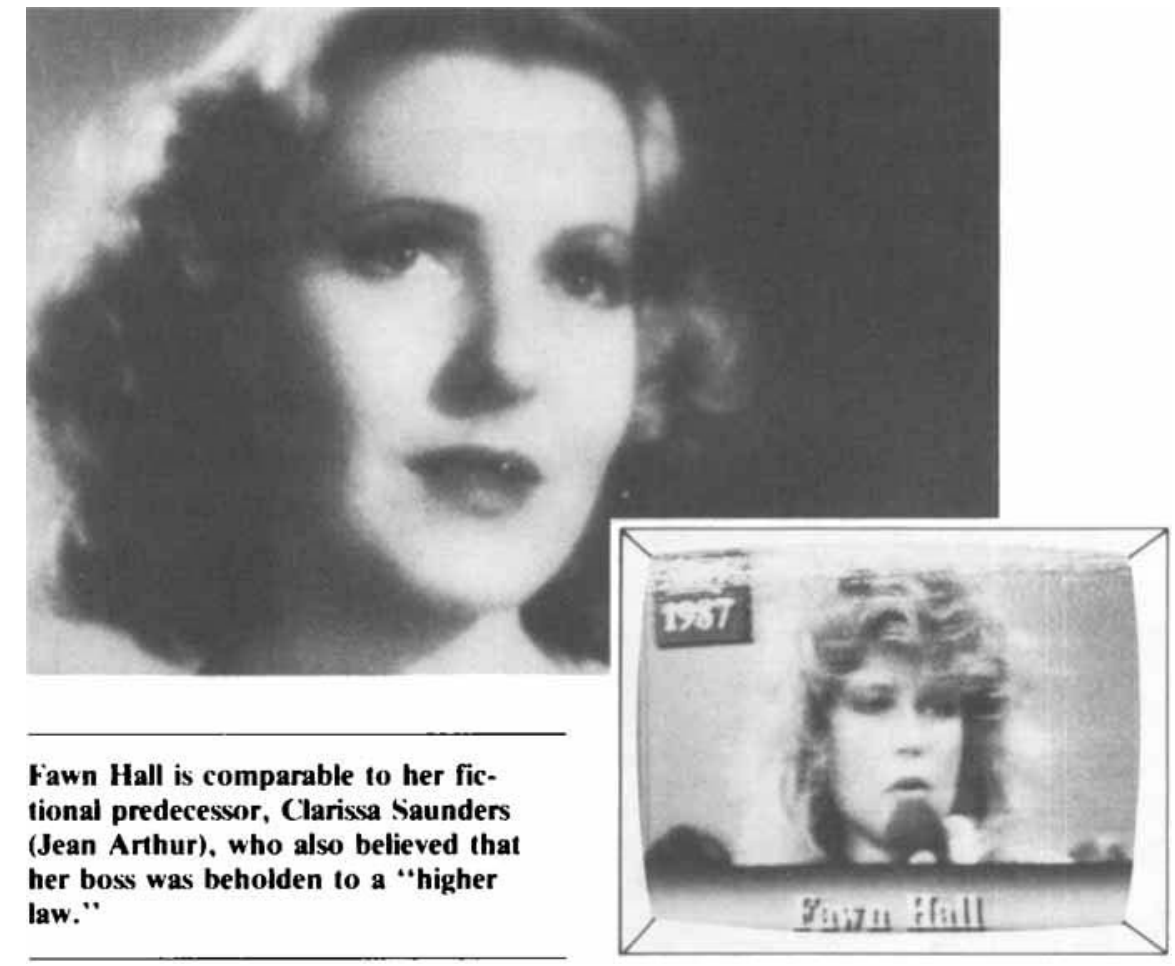

part because the colonel was able to bask in the glow of the accumulated "surplus sincerity" since Jimmy Stewart. So, unlike Smith, who was nearly destroyed by the media, North triumphed through its skillful use and attained celebrity status in the process-because, in our televisual era, credibility has replaced reality as the epistemological basis for truth. Even Senator Inouye conceded North's turnaround: "I believe that during the past week, we have participated in creating and developing . . . a new American hero."6 As Reagan proved, a performance that generates "the sincerity effect" can be more effective than genuine sincerity.

The heartfelt appeals to history in Mr. Smith (however mythicized) have been displaced to the more immediate and cynical power of the television screen in "The Ollie North Show." In the Capra original, innocence and Norman Rockwell values prevailed, whereas in the 1987 "remake," decadence and corruption (the financial dealings and lying to Congress) abounded but were mitigated by the familiar American myth of the country bumpkin who outsmarts the city slickers. The sociopolitical reality of the public hearings, then, was inter- textually structured around an unconscious "master narrative" of a common-sense hero who bests the experts (in this case, our elected representatives) and thus aids the nation by reaffirming traditional beliefs in our national identity (the subversion of the Constitution not withstanding). In this case, that national identity was moreover redefined by privileged white male WASPs to include lying and lawbreaking. But by satisfying a repressed longing to reexperience national wholeness and values, this "return of the redressed" "also fulfilled a more insidious ideological function: to paint a corrupt and illegal operation with the glowing brush of a corruption-fighter, Jimmy Stewart's Jefferson Smith.

\section{Formal Qualities: The Form of Ideology/The Ideology of Form}

The "formal" and stylistic properties of "The Ollie North Show"-its narrative, characterizations, camera angles, mise-en-scène, lighting, editing, and iconography-all helped to "speak" the text's ideology to the American public. The specific similarities and differences between the hearings and the Capra "original" can elucidate this ideology of style. In 
the Capra version, for instance, reaction shots of sympathetic spectators in the Senate gallery led the audience to react positively to Smith's patriotic orations. The television hearings also used positive reaction shots to cue viewers to side with North. The protagonist-antagonist dramaturgy was often articulated by crosscutting between North alone in close-up and the committee arrayed against him in medium shot (or skeptical members in close-up). Even a split screen effect was used to convey the David versus Goliath confrontation, with congressional counsel Arthur Liman getting the dominant screen-right position.

Framing conveyed the idea that Smith was in precarious or vise-like situations, whereas North was composed in more stable configurations. Low-angle shots up at the committee established its power over North, who was often shot from the high angle of the underdog. Forceful hand gestures showed the vigor and conviction of both heroes. Low-key lighting in the Capra film articulated the sinister, behind-the-scenes corruption of boss Taylor and his cronies, as well as Smith's Gethsemene, whereas North got halo-like rim lighting for his holy zeal. Smith's swearing-in ceremony was shot from behind, making him only one of many in the collectivity of the government and people. North took his oath in a low-angle frontal shot, visually authenticating his confrontational individual power and dominance.

The famous montage of patriotic monuments seen by Mr. Smith was re-echoed verbally in the North hearings by Senator Inouye's symbolic "sound montage" on the concluding day: "From the beginning of the history of mankind, organized societies ... have nurtured and created heroes [who] serve as a cement to unite people, to bring unity in that nation. . . . In the Capitol in Statuary Hall, each state has honored two of their heroes. ... And if you look down the majestic mall, you will see the monument of George Washington. . . . Then if you go further down you'll see the Lincoln Memorial." "Inouye's description fol- lows the exact order in which these landmarks (Capitol, Washington Monument, and Lincoln Memorial) were presented in $M r$. Smith's patriotic montage sequence.

\section{Socially Situated Viewers: History and Popular Memory}

The late Raymond Williams once succinctly characterized culture as "the signifying system through which the social order is communicated, reproduced, experienced, and explored." With that in mind, it is easy to see how documentary television fulfills a certain complicit conservative public function during legitimation crises. In confusing times,

Both the Capra film and the TV hearings used positive reaction shots to elicit sympathy for their respective heroes.

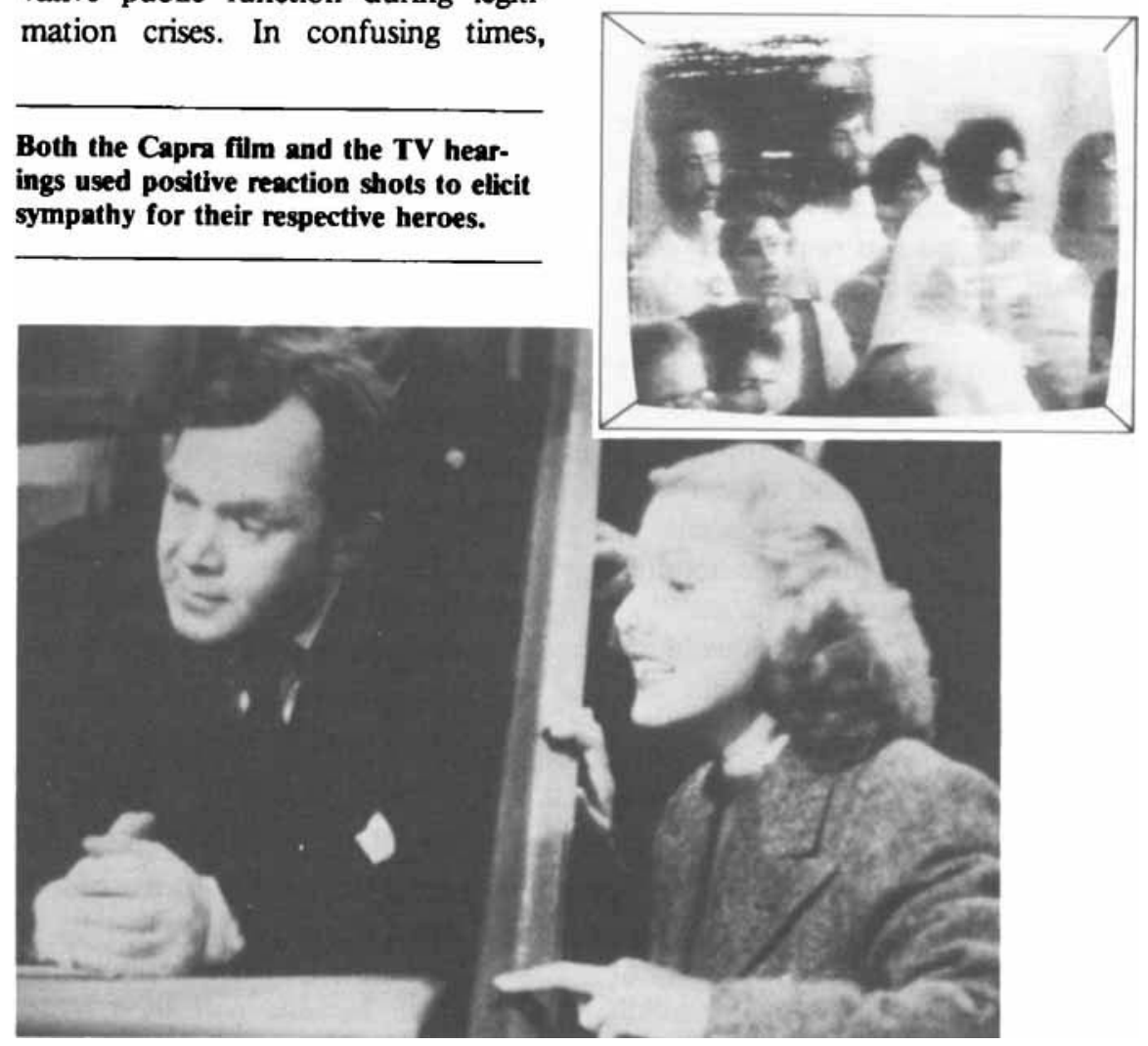

television, as a mass media, enhances the social psychology of identification and collective catharsis by which a nation can delegate a fictional or nonfictional representative as its historical stand-in. The unconscious political effectivity is especially reassuring when that hero is "always already" a familiar figure in a stock situation.

Certainly, the narrative of history has always been mediated. Historians, politicians, and teachers have always stood between the actuality of historical events and the participants and observers of those events. The television institution and its apparatus, however, complicate the mediating process exponentially because "live coverage" of newsworthy events ostensibly provides the viewer with unmediated access to contemporary "reality." But because any significant distinctions between reality and mediation, history and its representation, have become blurred, "all public discourse increasingly takes the form of entertainment."' 10 To paraphrase Irving Berlin, "There's no business but show business." "1

The political stakes are no more

nor less than the hold on what Michel Foucault called "popular memory." And that memory has been in the hands of the political Right for many years now. After all, who "speaks" Mr. Smith Goes to Washington and the Iran-Contra hearings? In both cases, dominant ideology speaks the text; that is, American social and political myths and institutions write the texts of popular films and political facts, because to renew social cohesion during periods of "legitimation crisis," 12 nations frequently resort to 


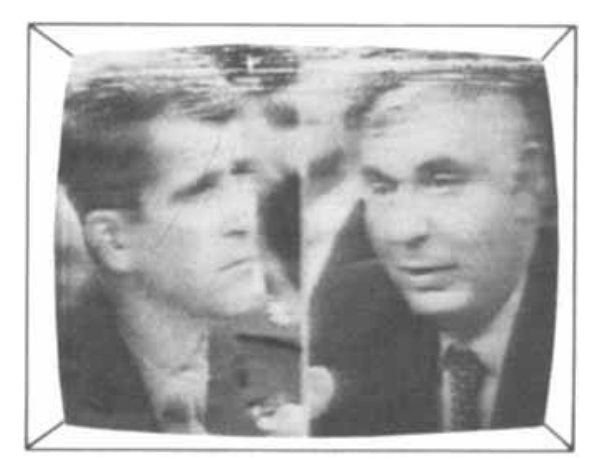

Split screen effects were used to convey the David versus Goliath confrontation, with congressional counsel Arthur Liman getting the dominant screen-right position.

retrospective gestures, what the French call "la mode rétro," to consolidate national unity. Again, Karl Marx delineated this re-presentational process: "The tradition of all the dead generations weighs like a nightmare on the brain of the living. ... They conjure up the spirits of the past to their service and borrow from them names, battle cries, and costumes in order to present the new scene of world history in this time-honored disguise and borrowed language." 13

For Marx, the French Revolution began like the Roman republic and became, under Napoleon, like the Roman empire. In Depression-era America, a nostalgic Capra-corn harkened back to a nineteenth-century agrarian populism. ${ }^{14}$ In Reagan-era America, the redeeming vision also came from the past, from the popular memory of a popular film, retrieving and solidifying a shaky status quo by grafting the populism of Capra onto the popularity of Reagan. Hayden White's recent book, The Content of the Form: Narrative Discourse and Historical Representation, suggests that history is given meaning only by our narrative imaginations. According to White, we invest history with meaning when our narrative capacities transform the present into a fulfillment of a past from which we wish we were descended. But whose narrative imagination are we relying on? White's or Reagan's? Capra's or North's?
Eco's definition of representation as "everything which can be used in order to lie" 15 applies to both artistic representation in the Capra film and the scandal-ridden political re-presentation in the North hearings.

The political scandal has emerged as one of the major spectacles of our age. It can be commodified like any other consumer product in the "society of the spectacle." Indeed, for Guy

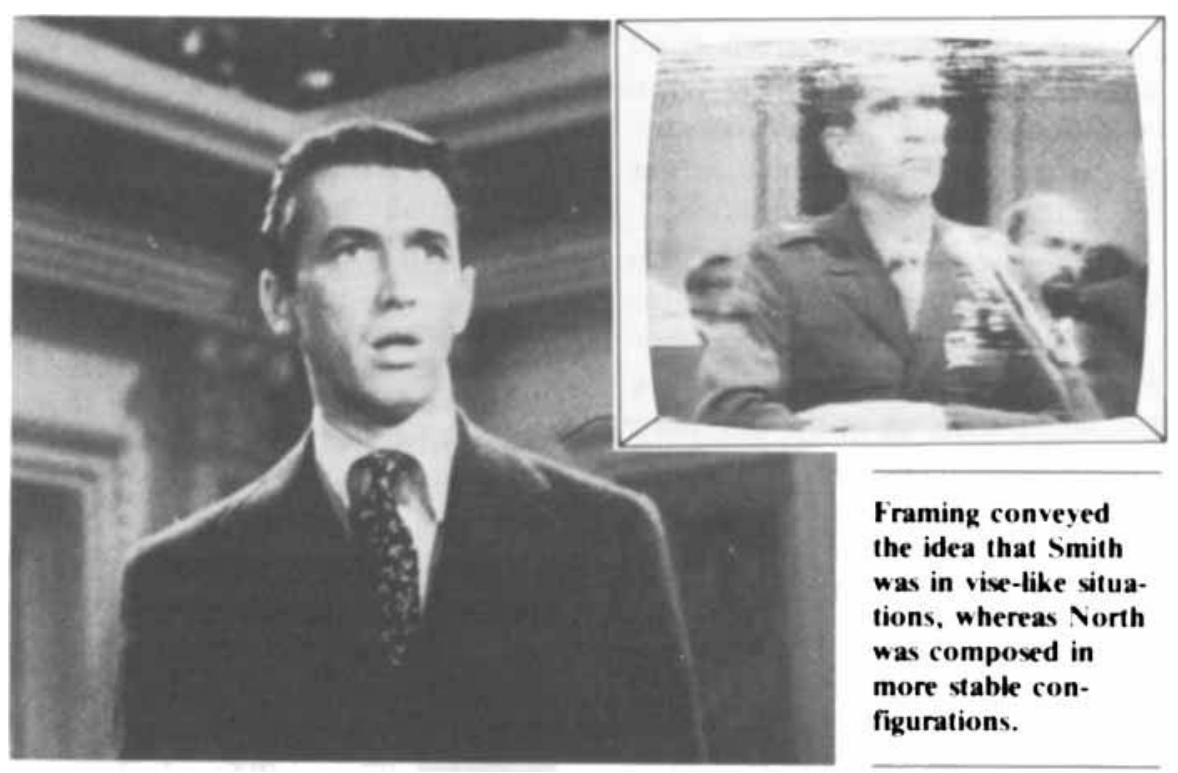

Debord, "The image is the last stage of commodity reification." 16 To quote Theodor Adorno, "Cultural entities typical of the style of the culture industry are no longer also commodities, they are commodities through and through.",17 Thus, consumer items such as Ollie T-shirts, videotapes, buttons, published accounts of the hearings, and fashion photos of Fawn Hall become part of a larger "text of texts," one that consists of assorted "incrustations" and "sedimentations" that circulate throughout the culture. ${ }^{18}$

Fredric Jameson notes that history is not a text because it is non-narrative and nonrepresentational, but he also adds that "history is inaccessible to us except in textual form . . . by way of prior (re)textualization." 19 Television's "liveness epistemology",20_its ability to record events as they happen and create the illusion of active participation in the making of history-is severely compromised by the ways ficcoming what Late Night host David Letterman calls "info-tainment." Because television has made entertainment the reified form of representation of all experience, the Iran-Contra hearings as they were televised are not reality; they are a TV show like any other and, as such, a congenial adjunct of show business, whose supraideology is entertainment.

On the tube and off, the entertainment regime of the televisual model has become the primary mode of knowing about the world-and that is profoundly ideological. After all, the "consciousness industry" (Hans Magnus Enzensberger's term) owns not only the means of production but the means of production of meaning as well. The "news," then, is a euphemism for the instantaneous ideological images that determine political reality for a vast majority of the American people. In the case of "The Ollie North Show," the televised depiction and re-presentation of lived history were dependent on prior fictional representations in an infinite regress of intertextual allusions. In this case, then, "media-ated" culture did not really document historical reality; instead, it provided reprocessed and shop-worn "useful fictions" to a mass audience.

With the help of the new technological media of reproduction and dis- tion has penetrated even the news, be- 
semination, monopoly capitalism has been able to decontextualize history and reprocess it as myth, since televisual discourse hardly permits time for a historical perspective. Instead, television transmogrifies history into diversion. Specific news messages may not be communicated to the mass audience, but powerful "images," definitions, and agendas may be set. The Colonel North persona, then, did not so much offer the audience an image of himself as offer himself as a compelling image of the audience. Thus, the question of whether television shapes or reflects our culture has largely disappeared since television has gradually become our culture. As Neil Postman notes, "TV's ecology, which includes not only its physical characteristics and symbolic code, but the conditions in which we normally attend to it, is taken for granted, accepted as natural." ${ }^{21}$ Ipso facto, public understanding of political events is shaped by the inherently reifying biases of television.

\section{Conclusion}

Coming to terms with the past can be a useful psychic process of remembering and working through for both the individual and society. But did "The Ollie North Show" help America come to terms with its past, or,

Forceful hand gestures showed the vigor and conviction of both heroes.

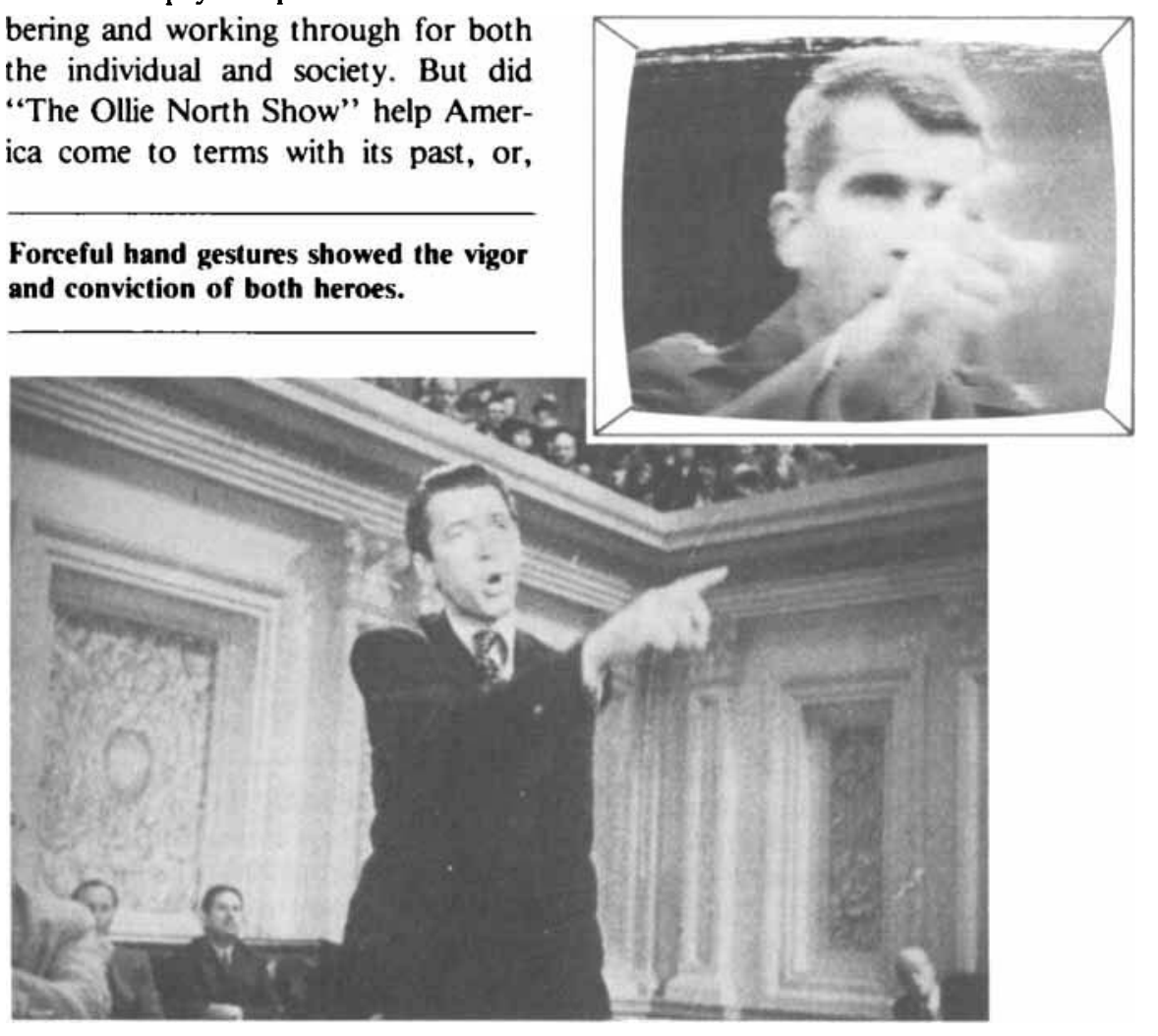

rather, did it allow the tarnished present momentarily to shine through the polish of a classic Capra film? In The Pleasure of the Text, Roland Barthes said that, "The bastard form of mass culture is humiliated repetition: content, ideological schema, the blurring of contradictions-these are repeated, but the superficial forms are varied: always new books, new programs, new films, news items, but always the same meaning.",22

This paradox provokes an even larger theoretical critique. By relegating history to the dustbin of an obsolete episteme, in short, by consigning history to the dustbin of itself, and by arguing that history does not exist except as text-and endless textuality at that (i.e., as historiography)-we approach meaninglessness. If the "referent" of historiography, what historians write about, is in fact eliminated, then history is indeed "up for grabs." When Hayden White lamented the "burden of history" in 1966 and suggested accepting discontinuity and chaos, he had no way of envisioning the political and cultural constellations of the 1980 s. $^{23}$

The history that was up for grabs in the 1960 s went to the political Right in the 1980 s, and it is thus vitally important not to abandon history to tradition-mongering neoconservatives bent on reestablishing and recuperating the norms and forms of earlier industrial capitalism through intertextuality. History as posthistoire becomes the reproduction of a reproduction. It is no longer reality in itself that provides the content but rather a secondary reality - in this case, a portrait of a mass idol as a clichéd image that appears over and over again in the mass media and that sinks into the consciousness of a mass audience. In this context, intertextuality functions as a quick fix of historical citation more typical of "reactionary postmodernism" than of a "postmodernism of resistance.",

To those who say that intertextuality offers possibilities for genuine radical change, one could counterfactually assert that the postmodern "raiders of the lost arcadia" produce only a simulacrum, a social imaginary that wraps contemporary Reaganite wolves in the sheep's clothing of the Capraesque past. Whatever its theoretical potential, in practice the use of tradition so endemic to intertextuality often results in aesthetic and political recuperation rather than in innovation and breakthrough. Societal shibboleths are reinforced and reified in the process. To cite Adorno again, "Every step forward is at the same time a retreat into the remote past. As bourgeois society advances, it finds that it needs its camouflage of illusion simply in order to exist." 25 Thus, at this historical juncture, it might be less important to come to terms with the past than to come to terms with television-by demystifying and dereifying its ideological agenda. And although David James is correct to note that "television is the postmodern mutant form of film, and in it both illusionist narrative and its discontents, both the entertainment industry and its opposition to it, are subsumed in the same hegemony," ${ }^{26}$ nonetheless, the tools of advanced media theory can be marshalled, as Marx said, "not just to explain the world but to change it." 


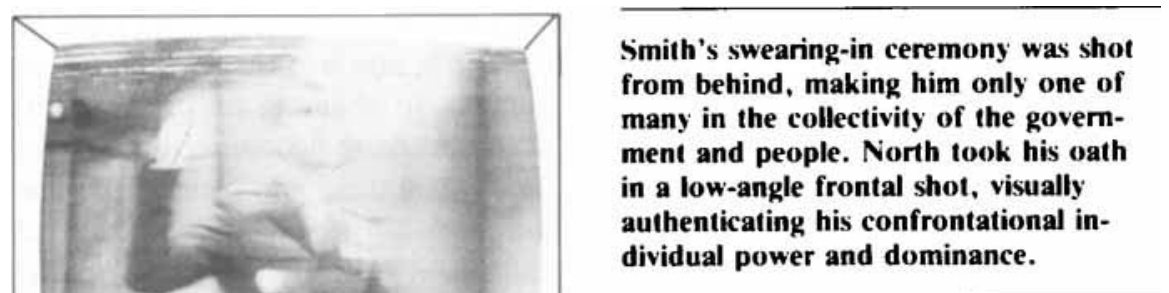
dividual power and dominance.
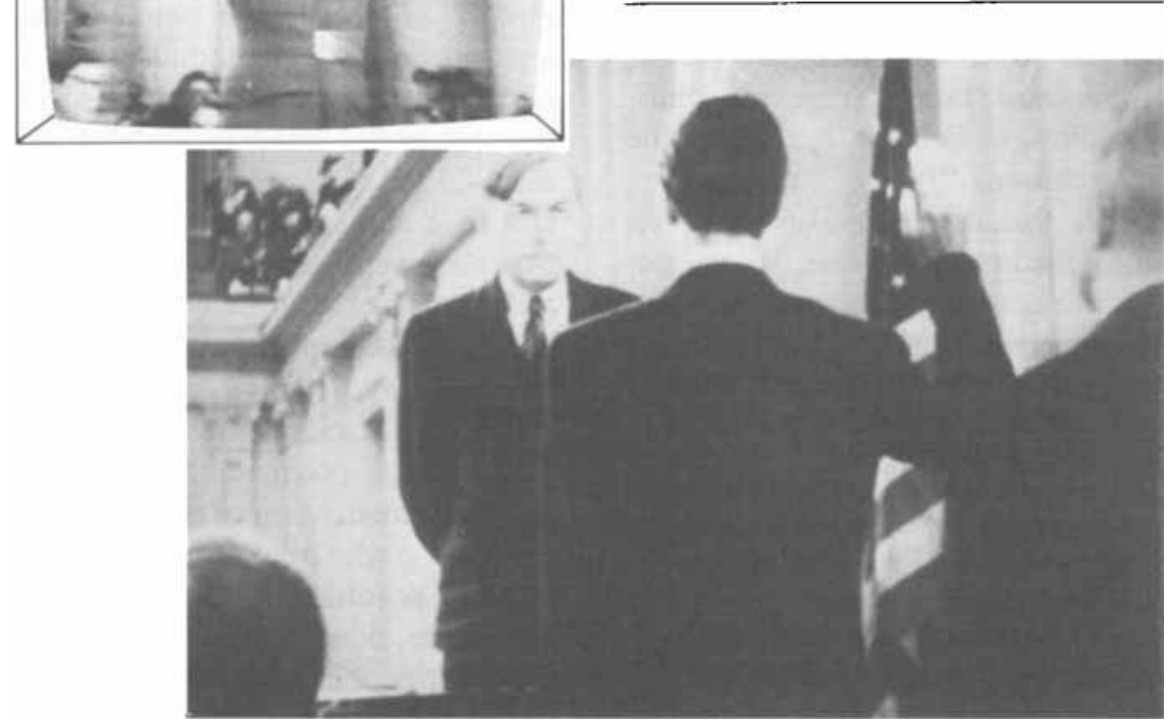

To return to John Fiske, "The power domain with which popular culture works is largely. . . that of semiotic power. The power to construct meanings, pleasures, and social identities that differ from those proposed by the structures of domination is crucial." 27 To update The Communist Manifesto, "all history on $T V$ is the history of class struggle," and that struggle goes on in our living rooms and classrooms, because texts impel but do not compel their own readings. And that constant struggle to "read against the grain" is imperative, for as Walter Benjamin said, "In every era the attempt must be made anew to wrest tradition away from a conformism that is about to overpower it.",28

\section{NOTES}

1. John Fiske, Television Culture (London: Methuen, 1987), p. 16

2. Karl Marx, The Eighteenth Braumaire of Louis Bonaparte (New York: International, 1963), p. 15.

3. Two studies that exemplify this approach are, respectively, Kristin Thompson's "Ivan the Terrible and Stalinist Russia: A Re-examination," Cinema Journal, 17, No. 1 (Fall 1977), pp. 30-43, and Frank P. Tomasulo's "Mr. Jones Goes to Washington: Myth and Religion in Raiders of the Lost Ark," Quarterly Review of Film Studies, 7, No. 4 (Fall 1982), pp. 331-340.

4. Umberto Eco, "Casablanca: Cult Movies and Intertextuality," paper presented at the Toronto Semiotics Circle, University of Toronto, 18 June 1984

5. Nick Browne, "The Politics of Narrative Form: Capra's Mr. Smith Goes to Washington," Wide Angle, 3, No. 3 (1979), pp. 4-11.

6. Taking the Stand: The Testimony of Lieutenant Colonel Oliver L. North (New York: Pocket, 1987), p. 749.

7. The pun on the Freudian concept of the "return of the repressed" (Weiderkehr des Verdrangten) is meant only half humorously. The process whereby repressed (or "redressed") material reappears in distorted form has serious consequences for both the individual and the "political unconscious." See Sigmund Freud, "Repression," The Standard Edition of the Complete Psychological Work of Sigmund Freud, trans. and ed. by

8. Taking the Stand, pp. 748-749.

9. Raymond Williams, Communications (London: Penguin, 1968), p. 11.

10. Neil Postman, Amusing Ourselves to Death: Public Discourse in the Age of Show Business (New York: Penguin, 1984), p. 4.

11. Postman, p. 98. James Strachey, 24 volumes. (London: Hogarth, 1953-66), Vol. 14, pp. 141-159.
12. Jürgen Habermas, Legitimation Crisis, trans. Thomas McCarthy (Boston: Beacon, 1975), pp. 46-48, 68-75.

13. Marx, p. 15.

14. Jeffrey Richards, "Frank Capra and the Cinema of Populism," in Movies and Methods, ed. Bill Nichols (Berkeley: University of California Press, 1976), pp. 65-77.

15. Umberto Eco, $A$ Theory of Semiotics (Bloomington: University of Indiana Press, 1979), p. 7.

16. Guy Debord, quoted in Fredric Jameson, Foreword to The Postmodern Condition: A Report on Knowledge, by Jean-Francois Lyotard, trans. by G. Bennington and B. Massumi (Minneapolis: University of Minnesota Press, 1984), p. $\mathrm{xv}$.

17. Theodor W. Adorno, "Culture Industry Reconsidered," trans. A. G. Rabinbach, New German Critique, 6 (Fall 1975), p. 13

18. Tony Bennett and Janet Woolacott, Bond and Beyond: Fiction, Ideology and Social Process (London: Macmillan, 1987), p. 17.

19. Fredric Jameson, The Political Unconscious: Narrative as a Socially Symbolic Act (Ithaca, NY: Cornell University Press, 1981), p. 82.

20. Postman, p. 112.

21. Postman, p. 79.

22. Roland Barthes, The Pleasure of the Text, trans. Richard Miller (New York: Hill and Wang, 1975), pp. 41-42.

23. Hayden White, "The Burden of History," in Tropics of Discourse: Essays in Cultural Criticism (Baltimore: Johns Hopkins University Press, 1978), pp. 27-50.

24. Hal Foster, "Preface," The AntiAesthetic: Essays on Postmodern Culture, ed. Hal Foster (Port Townsend, Washington: Bay Press, 1983), pp. ixxvi.

25. Theodor W. Adorno, In Search of Wagner, trans. Rodney Livingstone (London: New Left, 1981), p. 95.

26. David James, "Hardcore: Cultural Resistance in the Postmodern," Film Quarterly, 42, No. 2 (Winter 1988-89), p. 31.

27. Fiske, p. 317.

28. Walter Benjamin, "Theses on the Philosophy of History," in Illuminations, trans. Harry Zohn and ed. Hannah Arendt (New York: Schocken, 1969), p. 255.

FRANK P. TOMASULO is an associate professor in the Cinema and Photography Department at Ithaca College. He is currently on leave of absence, teaching film history and theory at the University of California, Santa Cruz. 